\title{
SLS/BIALL Academic Law Library Survey 2015/2016
}

\section{David Gee}

Deputy Librarian

Institute of Advanced Legal Studies, School of Advanced Study, University of London

By-line This is the latest report analysing the results of the Society of Legal Scholars and BIALL Survey. It has been written by David Gee, Deputy Librarian at the Institute of Advanced Legal Studies, School of Advanced Study, University of London

\section{Summary of key findings}

- The response rate was $86.61 \%$; a new record, the previous record was $85.4 \%$ (section 3);

- There was a slight decrease in universities enrolling PhD and MPhil students, with $98 \%$ of old universities and $73 \%$ of new universities enrolling these type of students (section 5);

- $20 \%$ of respondents (same as last year) failed to meet the SLS Statement of Standards 3.1 on space and physical facilities, through not housing all relevant collections in one place (section 6);

- The ratio of students to seats without a PC workstation continued to worsen to its least favourable since statistics were first collected in the 1990s, with a median of 6.53 students to every seat in study areas by the law collection and a mean of 10.99 students per seat. Some respondents noted the difficulty of accurately identifying such seating where the law collection is just one of many collections or activity areas on a particular floor of the library building (section 7);

- On the other hand, the ratio of students to PC workstations located adjacent to the law collections and in the law school has improved to its most favourable ever with a median of 1.79 students to every PC workstation and a mean of 3.64 students per workstation, although some respondents noted difficulties when trying to identify accurately the number of PC workstations earmarked specifically for the use of law students (section 8);

- For the first time the survey directly asked respondents if the number of PC or Mac workstations have decreased. Ninety five (or $98 \%$ ) of respondents answered. However only 7 (or $7 \%$ ) of respondents said that the number of PC or Mac workstations had decreased (section 8);

- For the first time the survey also asked about the number of laptops / tablets available for short-term loan to students. Sixty-eight (or $70 \%$ ) of respondents provided figures. The range was 2 to 200 loanable devices, with a mean of 62 loanable devices and a median of 50 loanable devices (section 8);

- WiFi access was almost universally available within libraries in general, but still less frequently available in the law collection itself (section 8);

- $23 \%$ of respondents reported an increase in the number of visits to the law library; $55 \%$ said numbers were constant and $22 \%$ reported a fall (section 9);

- The results for term-time weekday opening indicate that there has been a significant increase in the number of libraries open for longer and a marked increase in the number of libraries opening for more than 100 hours per week. Moreover, the median and average vacation opening hours significantly increased on 2014 as well (section $10)$; 
- 36 libraries (13 old universities and 23 new universities) stated that they provided 24 hour access throughout the term to their paper-based collections. Overall this is a marked increase on the 26 libraries in 2014 (section 10);

- Staffed issue services were available for a longer time period, on average, than previously, whilst $96 \%$ of libraries provided self-issue (section 10);

- There was a very slight decrease in the average number of hours a reader enquiry service for law was provided by professionally qualified staff (section 10);

- $62 \%$ of libraries serving distance learning students provided three basic services: a link to the catalogue, a link to full-text databases and a link to full-text materials scanned into the VLE (section 11);

- The three most popular law databases in terms of number of subscriptions continued to be Westlaw UK, Lexis®Library and HeinOnline. But there was still some fluidity in the range of subscriptions held, for $14 \%$ of respondents were considering cancelling a subscription to an electronic source before the end of July 2017 whilst $9 \%$ were considering a new subscription before the same date (section 12);

- The median number of legal database subscriptions taken in responding libraries in February 2017 was 6 and the average number was 8 databases. The numbers of legal databases offered by institutions ranged from 1 to 49 (section 12);

- JSTOR was still the most widely used general database in law libraries (section 13);

- Nexis UK and Proquest continued to be the two most widely subscribed to newspaper databases which are used to contribute significantly to teaching and research in law schools (section 13);

- As a result of subscribing to law e-journal databases, $48 \%$ of those with access had cancelled a print subscription to a law journal (section 14);

- $39 \%$ of respondents said they had cancelled subscriptions to the print version of law material during the current year, where the same resource was available electronically (section 14);

- Law journals and law reports were most frequently cut. Respondents most frequently said that the cuts were made on the basis of the availability of an electronic alternative. The second most frequent reason was that the cuts had to fall on UK materials because there were either, very few or no FCIL materials held. And the third most frequent reason was that the titles concerned simply had low usage (section 14);

- The three most popular e-book publishers in terms of number of subscriptions were Dawsonera, My-i-library and EBL (section 14);

- Mean expenditure on law materials decreased by $7.46 \%$ across all respondents on the level in 2015 . Old universities reported a slight $0.85 \%$ increase in mean expenditure on 2015 , whilst new universities reported a marked $12.88 \%$ decrease in mean expenditure on 2015 (section 15.1);

- This year the mean spend per student at new universities has overtaken the mean spend per student at old universities. Mean law materials expenditure per student in old universities was £205, whereas in new universities it was higher at £232. The trend in this area is therefore of a widening gap between sectors (section 15.1); 
- The proportion of total law material expenditure on monographs increased by $1 \%$ to $23 \%$, serials continued its downward trend to its lowest ever percentage of $37 \%$ and databases increased to $40 \%$ (section 15 );

- Separate results on overall expenditure on law library materials in institutions not providing vocational or professional award courses are provided (section 15.7);

- The highest proportion of income to fund the acquisition of law materials continued to come from general library funds (section 16);

- $69 \%$ of all law schools made no contribution at all to funding the acquisition of law materials. However, of those law schools that did contribute, they appeared to do so more generously with the mean amount contributed by law schools increasing by $3.8 \%$ on last year (section 16);

- $17.5 \%$ of responding libraries did not have any library staff which spent $50 \%$ or more of their working time on the care and servicing of the law collection. Several explained that their activities were being diluted into library-wide responsibilities or the law collection was being serviced from a team of staff with wider subject duties (section $17)$;

- Overall average staffing numbers slightly increased in old universities to 3.60 FTE and slightly increased in new universities to 2.52 FTE (section 17);

- $81 \%$ of respondents had at least one member of law library staff who had a LIS qualification, although for 20 institutions this was less than one full-time member of staff (section 17.4);

- As found in previous surveys, library staff with law qualifications were much more common in old universities (section 17.4);

- $78 \%$ of respondents were aware of the revised SLS Statement of Standards (2009 version) and $47 \%$ had used the Statement in discussions on funding and administration (section 18);

- A majority of $53 \%$ of respondents considered a significant move towards electronic provision likely in the next five years (section 19.1);

- $60 \%$ of respondents felt that over the next five years the proportion spent in their library on the purchase of law monographs as compared with law serials would remain constant (section 19.2);

- $59 \%$ of respondents considered that over the next five years the proportion spent on purchasing legal materials relating to the law of Great Britain and European Union as compared with foreign and international law would remain constant. Interestingly, the next largest group of law libraries (20\%) thought the proportion spent would move marginally in favour of purchasing more legal materials relating to the law of Great Britain and European Union (section 19.3).

The following report outlines the activities and funding of academic law libraries in the UK and Ireland in the academic year 2015/2016. The figures have been taken from the results of a survey questionnaire undertaken by Academic Services staff at the Institute of Advanced Legal Studies on behalf of the Society of Legal Scholars (SLS). 
This survey has been run on an annual basis since 1996 and reported in The Law Librarian and latterly in Legal Information Management. It is sponsored either by the British and Irish Association of Law Librarians (BIALL) or by the Society of Legal Scholars (SLS).

I shall attempt to draw comparisons with previous surveys where helpful. In particular "2015" refers to the 2014/2015 data (Gee, 2016), "2014" refers to the 2013/2014 data (Gee, 2015) and "2013" refers to the $2012 / 2013$ data (Gee, 2014). All the surveys referred to are referenced at the end of the report.

Finally I am very pleased to note that this ongoing research project to publish a report on the SLS/BIALL annual survey of law libraries in the UK and Ireland received national recognition in June 2016 when it received the BIALL Wallace Breem Memorial Award:

http://ials.sas.ac.uk/news/Library Wallace Breem Memorial Award 2016.htm.

\section{$2 \quad$ Methodology}

The survey methodology followed the improvements made three years ago, conveniently making an electronic editable PDF form version of the survey questionnaire available to be completed. In March 2017 an email containing both a link to the survey questionnaire on the IALS website and an attached editable PDF form was dispatched to 112 institutions in the UK and Ireland. Respondents could therefore complete the electronic questionnaire at one sitting, save it under the name of their institution and email it back to us. Alternatively they could print out the questionnaire to work on over a period of time and then complete the electronic version, save it and email it back to us. We were also still happy to receive completed paper versions of the survey questionnaire by post if this was the method preferred by individual respondents.

As in the past research centres with no students or only small numbers of postgraduates where the main university law library was invited to respond to the survey, were excluded. For similar reasons, the Oxbridge college libraries were excluded but, as usual, responses from the Bodleian and Squire law libraries were invited.

This year's survey is funded by the Society of Legal Scholars (SLS). A copy of the questionnaire is available on the IALS website at: http://ials.sas.ac.uk/library/ials-informationinitiatives/slsbiall-academic-law-library-survey.

\section{$3 \quad$ Response rates}

This year 97 forms were returned from 112 libraries representing a response rate of $86.61 \%$, an increase on last year's $83.78 \%$ and a new record (the previous record of $85.4 \%$ was set in 2003/2004). I am very grateful to all those law librarians who took the time to respond. I am not usually made aware of the reasons for non-returns, but this year I was told that several libraries were recruiting new law librarians and this explained why they did not return a completed questionnaire. Another key reason for non-returns was that law librarians are finding it difficult to extract relevant data (particularly financial data) from the central university. On our part we tried to be very flexible and have permitted some respondents to take up to eight weeks to send in a promised return.

A response rate of over $86 \%$ is very welcome and should permit the presentation of a reasonably accurate picture of academic law libraries in the UK and Ireland. A complete list of the academic law libraries that returned a completed 2015/2016 survey questionnaire is contained in the Appendix.

To help detect patterns in law library provision, the data has been analysed, as in previous years, by type of institution:

- "old" universities incorporated before 1992

- "new" universities incorporated in or after 1992

- institutes of higher education and other types of institution 
Forty-three old universities responded (44 last year), as did 51 new universities (46 last year) and 3 other institutions ( 3 last year). The response profile has therefore changed slightly, with one fewer results for old universities and five more results from new universities. This may affect comparisons with past results.

\section{$4 \quad$ Definitions}

In many of the following sections, the survey responses are analysed using range, mean and median.

- The range indicates the smallest and the greatest value of the responses and helps us understand the diversity of responses.

- The mean has been calculated by adding up all the responses and dividing by the number of responses to get an "average". The mean can be distorted by one or two responses which are very large or very small.

- The median is the mid point and is calculated through ordering the responses by size from the smallest to the greatest and finding the middle response. There will be an equal number of responses below the median and above the median and so it provides a benchmark of what a "typical" university is doing.

Percentages from this point onwards have generally been rounded to the nearest whole number.

\section{$5 \quad$ Student numbers}

A representation of the number of law students served by the libraries helps in understanding the framework in which provision is made and can assist librarians in comparing their provision with institutions of similar sizes.

Respondents were asked to indicate the total number of taught course students (bodies, not FTEs) in the Law School enrolled on exempting undergraduate law degrees or professional or academic postgraduate courses in law. Ninety two out of the total of 97 respondents gave figures for student numbers, ranging from 50 to 12,047 (50 to 7,639 in 2015). The median number of law students was 643 (637 in 2015) and the mean number was 937 (892 in 2015), both figures therefore increasing year-on-year.

Respondents in old universities reported student numbers between 50 and 2,091 (50 to 1,800 last year), with a mean of 883 (852 last year) and a median of 801 (817 last year).

In new universities, the range was 100 to 12,047 (80 to 7,639 last year), with a mean of 1,033 (968 last year) and a median of 505 (521 last year).

Among the 3 other institutions, the range was 64 to 202 (70 to 192 in 2015). The mean was 124 (131 in 2015) and the median was 106 (131 in 2015).

Mainly upward trends are evident in the number of students attending responding institutions in $2015 / 2016$ as compared with the previous year. In particular the average number of students in both old and new universities have increased.

Ninety-six or $99 \%$ of respondents (91 or $98 \%$ in 2015) offered an exempting undergraduate law degree. Thirty one or $32 \%$ of respondents (28 or 30\% in 2015) hosted the Legal Practice Course (LPC) or Bar Professional Training Course or Diploma in Professional Legal Practice (Scotland) or Professional Practice Course (Ireland) or Degree of Barrister-at-law (Ireland). This represents $21 \%$ of old university respondents, $41 \%$ of new universities and $0 \%$ of other institutions.

Twenty two or $23 \%$ (23 or $25 \%$ in 2015 ) of respondents provided courses leading to other law professional awards, such as the CPE or Chartered Institute of Legal Executives qualification. 
$16 \%$ of old universities, $25 \%$ of new universities and $67 \%$ of other institutions ran such courses.

The final category was for other taught courses, such as the LLM, which led to a postgraduate award in law. Eighty six or $89 \%$ (84 or $90 \%$ in 2015 ) of institutions ran these postgraduate courses, including $95 \%$ of old and $88 \%$ of new universities and $0 \%$ other institutions. The movements in the percentages of respondents offering particular courses this year are very small and are probably mainly due to changes in the survey profile.

Respondents also indicated whether the law school enrolled students onto research courses, such as those leading to $\mathrm{PhD}$ and MPhil. Overall 79 or $81 \%$ (80 or $86 \%$ in 2015) of institutions indicated that they did. $98 \%$ of old universities, $73 \%$ of new universities and $0 \%$ of other institutions had such students. Research students were not included in the count of law students detailed above. The percentage for old universities is down slightly on the $100 \%$ last year and the trend is down for the new universities at $73 \%$ (80\% in $2015,72 \%$ in 2014 and $66 \%$ in 2013).

This year we again asked about the number of students enrolled on distance learning courses for law. The question was last posed in 2014. Twenty nine institutions or $30 \%$ (2014: 26 or $29 \%$ ) offered this mode of study. Student numbers ranged from 3 to 1,538 (2014: 7 to 1,325$)$. The median number of students was 80 students (2014:58) and the mean 243 students (2014: 184). Twelve or $28 \%$ of old universities (2014: $22 \%$ ) had students enrolled on distance learning courses; the number of students ranged from 12 to 350, with a median of 73.5 students. Seventeen or $33 \%$ of new universities (2014: $30 \%$ ) had distance learning students, with numbers ranging from 3 to 1,538, and a median of 100 students. Although, in general, relatively small numbers of students are enrolled on distance courses, libraries provide special support arrangements which are investigated in section 11, below.

\section{$6 \quad$ Location of the law library}

Respondents were asked to indicate, from a list, which most closely matched the circumstances in their institution.

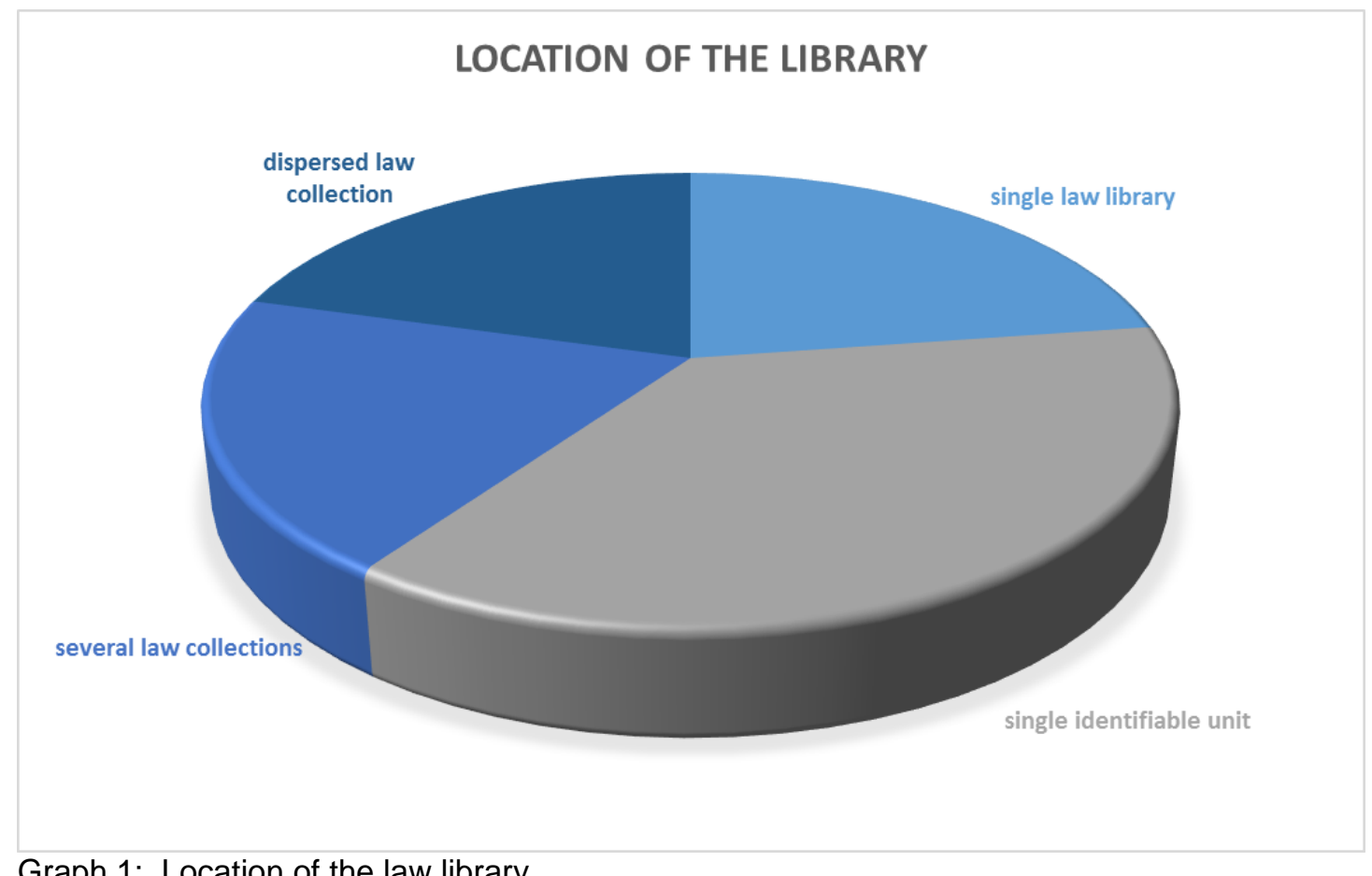

Graph 1: Location of the law library

As the above pie chart demonstrates, across all respondents: 
- $23 \%$ had a single law library in a location separated from other subject collections (23\% in 2015). Of these, there were 12 (2015: 13) old universities, 10 (2015: 8) new and zero (2015: 0) other institution.

- $\quad 37 \%$ had a law collection not so separated but shelved so as to form a single identifiable unit (39\% in 2015). These included 15 (2015: 16) old universities, 20 (2015: 19) new and 1 (2015: 1) other institutions.

- $\quad 20 \%$ had several law collections each in a different location (18\% in 2015). These included 8 (2015: 6) old, 11 (2015: 11) new universities and 0 (2015: 0) other institution.

- $20 \%$ had a law collection dispersed wholly or partly among other subject

collections (20\% in 2015). Of these, 8 (2015: 9) were old universities, 10 (2015: 8) were new universities and 2 (2015: 2) other institutions.

Twenty eight percent (2015: $30 \%$ ) of old universities responding had a single and separate law library, while $20 \%$ (2014: $18 \%$ ) of new universities and zero (2015: $0 \%$ ) of other institutions had a single and separate law library.

Thirty five percent (2015: $36 \%$ ) of old universities described their law collection as being shelved so as to form a single identifiable unit but not separate from other collections. Thirty nine percent (2015: $41 \%$ ) of new universities described their law collection in a similar way, and $33 \%$ (2015: $33 \%)$ of other responding institutions.

Nineteen percent (2015: $14 \%$ ) of old universities had several law collections, each in a different location, but $22 \%$ (2015: $24 \%$ ) of new universities and no other institutions $(0 \%)$ reported several collections (2015: 0\%).

As in past surveys, the main reason for more than one law collection was the establishment of a separate library targeted at vocational course students, such as those on the LPC or BPT, in addition to a main law collection. Other respondents mentioned other reasons for separate locations, for example, one respondent mentioned that a small separate law collection was needed for undergraduates and one mentioned that a small separate law collection was needed in in the main library.

The comments to the SLS Statement of Standards 3.1 (Society of Legal Scholars, 2009) on space and physical facilities require "the housing of all relevant collections ... as a unified whole in one place ...". This year the figures suggest that this criterion was not met by at least the $20 \%$ of institutions reporting dispersed collections.

Eighteen percent of old universities, $19 \%$ of new universities and $66.7 \%$ of other institutions had law collections wholly or partly dispersed among other subject collections. Last year the figure was $220 \%$ overall: in detail, in $2015,20 \%$ of old, $17 \%$ of new and $0 \%$ of other institutions had dispersed collections.

Although the overall percentage trend of dispersed collections has plateaued at $20 \%$ in both 2015 and 2016, one must remember that the general response profile for different types of institution has altered a little between last year's and this year's surveys, so the actual institutions responding are different and are probably partly the reason for the results noted.

\section{$7 \quad$ Provision of seating}

Respondents were asked to indicate the number of seats in study areas by the law collection/s, excluding workstation places. This question has been asked in alternate years so the data for 2016 can be compared with that for 2014, 2012 and 2010.

Eighty eight institutions provided figures. The figures ranged from 10 to 2,500 with a mean of 205 (2014: 205; 2012: 207; 2010: 204) and a median of 100 (2014: 100; 2012: 123; 2010: 
120). The results must be viewed with some caution. As has been noted in section 6 above, there is a significant number of institutions where the law collection is not separate from other subjects, and respondents have taken different views on how to count the amount of seating which was 'by the law collection' as required by the survey question.

A more useful measure is the ratio of students to seats. Eighty three of the 97 responding institutions were able to provide data for both variables. The ratio ranged from 0.25 to 94.4 students per seat, with a median of $6.53(2014: 6.42 ; 2012: 5.74 ; 2010: 5.7)$ and a mean of 10.99 students per seat $(2014: 9.07 ; 2012: 8.42 ; 2010: 8.20)$. The data was analysed according to the type of institution. The 38 old universities had a ratio of between 0.25 and 70.95 (2014: 0.43 and $24 ; 2012: 0.33$ and $36.1 ; 2010: 0.6$ and 15.9$)$ with a median of 4.01(2014: 6.09; (2012: 5.39; 2010: 4.83). The 42 new universities had a ratio of between 0.77 and 94.40 (2014: 1 and $61.22 ; 2012: 0.26$ and $80.89 ; 2010: 0.60$ and 56.60$)$ with a median of 9.26 (2014: $6.63 ; 2012: 6.64 ; 2010: 7.70)$. The 3 other institutions had a ratio of between 0.38 and 10.60 (2014: 0.89 and 14.39; 2012: 1.04 and 11.60; 2010: 1.70 and 13.40), with a median of 3.74 (2014: 10.55; 2012: 6.32; 2010: 4.69).

61\% (2014: 54\%; 2012: 58\%; 2010: $60 \%$ ) of old universities were at or below the overall median ratio of $6.53 \%$, as compared with $38 \%$ (2014: $48 \%$; $2012: 42 \% ; 2010: 38 \%$ ) of new universities and 67\% (2014: 33\%; 2012: 50\%; 2010: 60\%) of other institutions.

A further analysis highlights the differences between the various categories of respondent: $18 \%$ of old universities were in the quartile of respondents with the least favourable student to seat ratios, as compared with $33 \%$ of new universities and $0 \%$ of other institutions (2014: $15 \% ; 32 \%$ and $50 \%$ ). The percentage of old universities appearing in the quartile with the least favourable student seat ratios, is $3 \%$ higher than in 2012, while the percentage of new universities with the least favourable student seat ratios is 1\% higher than in 2012 .

The median ratio of students to seats in a selection of past surveys has been 1994: $3.50: 1$, 2004: 5.30:1, 2006: 5.60:1, 2008: 5.40:1, 2010: 5.70:1, 2012: 5.74:1 and 2014: 6.42:1. This year's ratio of $6.53: 1$ is the least favourable ever reported. Some caution should be expressed in using the student : seat ratio, for many librarians noted the difficulty of identifying the number of 'seats by the law collection', where the trend in design is towards seating areas provided according to different study environments (silent, quiet, group activity) rather than made available to serve a particular subject.

The ratio may be compared with the former University Grants Committee ratio for law libraries of 2:1. This ratio received indirect endorsement in the Follett Report of 1993. Further, the comments to SLS Standard 3.2 states that 'a ratio of students per seat exceeding 5:1 should be regarded as high and in need of early reduction, or of compensation through extended opening hours'. The survey results indicate that study space is under continuing pressure from student numbers in all sectors but, as discussed in section 10 below, there continues to be a considerable increase in the opening hours of responding libraries. Finally one could argue that this seemingly worsening position regarding the median ratio of students to seats without workstations may not be as unfavourable as it first appears as it may just mean that the overall number of seats have remained about the same, but that more seats are gaining a PC workstation. This argument is probably correct as we shall see from section 8 where the median ratio of students to workstations has decreased again to the most favourable ever reported.

\section{$8 \quad$ Workstations}

The survey asked respondents to indicate the number of PC or Mac workstations which can access electronic law materials, and are available for law student use:

- adjacent to, or in the same building as, the law collection

- in the building where the law school is housed. 
In response to the first part of the question, a number of respondents noted that although the workstations counted as 'in the same building as the law collections' they were shared with non-law students. It was difficult to determine accurately the numbers available for law student use. Further, some respondents not only included fixed workstations but noted the number of laptops available for student use. The questions on workstation provision were devised originally in the mid-1990s, when the SLS was concerned about the level of investment in IT hardware. But since then developments in library facilities and computer technology (and the availability of laptops and tablets for loan in many libraries) have made accurate tracking of the relative ease of law student access to IT much less reliable.

Eighty-eight respondents (91\%) provided figures for the numbers of workstations near the law collections. The numbers ranged from 0 to $1,763-51 \%$ (the median) had at least 219 (2014: 215, 2012: 203; 2010: 130) and the mean was 282 (2014: 275, 2012: 239; 2010: 218). The very positive trend of providing additional workstations to complement traditional study places seems to have increased still further.

Eighty-four respondents (87\%) provided figures for the number of workstations in the law school. Of these, 29 law schools did not have any workstations for student use (2014: 22). For those who did, the range was from 0 to 968 (2014: 0 to 585), with a mean of 81 (2014: 62) and a median of 23 (2014: 31). Comparing 2016 with 2014, the range of numbers and means have increased significantly. The median in 2014 has decreased on 2012; this may be due to changes in the responses profile.

The ratio of law students to workstations gives a more effective picture of the levels of provision. The figures for workstations adjacent to the law collections and in the law school were combined for this measure. 81 (2014: 81) institutions were able to provide data for both parts of the ratio.

The ratio ranged from 0.24 to 27 students per workstation, with a median of 1.79 (2014: 2.13) and a mean of 3.64 (2014: 6.99). Forty-five institutions had a ratio of law students to workstations of less than 2 students per PC (2014: 35). When interpreting these figures the comments at the beginning of this section should be noted: the difficulty of identifying accurately the numbers of PCs "in the same building as the law collections", where they were shared with non-law students.

As in the past surveys on this topic, the results for the average law student to workstation ratio were dissimilar in the old and new university sectors. In the 35 old universities, the mean ratio was 5.97 and the median was 2.56 (2014: 6.52 and 2.59). For the 43 new universities, the mean was 1.88 and the median was 1.38 (2014: 7.81 and 1.48). The figures for the 3 other institutions were a mean of 1.62 and a median of 1.54 (2014: 3.24 and 2.00).

The overall median ratio of students to workstations in a selection of past surveys has been 2010: 3.80:1, 2012: 2.34:1 and 2014: 2.13:1). This year's ratio of 1.79:1 is the most favourable ever reported. Although some caution should be expressed in using the student to workstation ratio, for many librarians noted the difficulty of identifying the number of 'workstations by the law collection'.

For the first time the survey directly asked respondents if the number of PC or Mac workstations had decreased. Ninety five (or $98 \%$ ) of respondents answered. However only 7 (or $7 \%$ ) of respondents said that the number of PC or Mac workstations had decreased. Of these 7 respondents, 3 gave "students bringing in own devices" as a reason; 2 gave "reduced budget" as a reason; and 5 gave "other" reasons such as: "some re-located to social learning spaces outside the library".

For the first time the survey also asked about the number of laptops / tablets available for short-term loan to students. Sixty-eight respondents $(70 \%)$ provided figures. For those who did provide loans, the range was 2 to 200, with a mean of 62 loanable devices and a median of 50 loanable devices. 


\section{WIFI access to law databases}

Ninety five (or 98\%) of respondents answered the question regarding the provision of WiFi access to law databases. Sixty eight $(72 \%)$ provided access adjacent to the law collection (2014: 74\%) and 95 respondents (or 100\%) provided access within the university or college library in part or whole (2014: 100\%). Ninety (or 95\%) provided WiFi access to law databases in the law school building (2014: $96 \%) ; 83(87 \%)$ in student halls (2014: $90 \%)$ and $91(96 \%)$ in other parts of the institution to which students have access (2014: 95\%). It is notable again that WiFi access is almost universal within the library in general, but less frequently available in the law collection in particular.

\section{$9 \quad$ Library use}

This year we continued to monitor trends in the number of visits to the law library, last measured in 2014. The aim was to determine whether increased access to law databases from outside the university or college campus had affected the number of visits to the library. The question asked respondents to compare the number of visits to the law collections in $2014 / 15$ with 2015/16. The question recognised that a level of judgement would be needed but asked respondents to note the basis for their comparison. Ninety one institutions responded. Twenty one institutions or 23\% (2014: 24\%) saw an increase in visits, in 50 or $55 \%$ (2014: $64 \%$ ) the number of visits remained constant, and in 20 or $22 \%(2014: 12 \%)$ the number of visits decreased. Therefore the majority of institutions reported that the number of visits remained constant.

Thirty two (35\%) respondents mentioned more than one basis for comparison. Personal observation was mentioned 66 times, exit gate logs 22 times, SCONUL statistics 12, issue desk statistics 8 , student numbers 7 , occupancy counts not attributed to SCONUL headcount 6 , one-to-one student appointment statistics 3, online usage statistics 3 , and shelving / feedback statistics 2 . The continued heavy reliance on personal observation as the basis for comparison might suggest the results are subjective rather than objective.

\section{Opening hours and services}

Opening hours were last surveyed in 2014. For the 95 responding libraries the median number of term-time weekly opening hours was 112 (2014: 103.5). The mean for weekly term-time hours was 125.17 (2014: 116.13). Hours ranged from 49.5 to 168 (2014: 52.5 to 168). Thirty six libraries (38\% of all respondents, 13 old universities and 23 new universities) stated that they provided 24 hour access throughout the term to their paper-based collections. Overall this is a marked increase on the 26 libraries in 2014. Sixty responding libraries were open for more than 100 hours per week (2014: 49); they were 26 old, 34 new and no other institutions (2014: 22 old, 27 new and 0 other).

Eighty nine respondents gave details of opening hours in vacation. The median for weekly opening times was 74 hours (2014: 54 hours) and the mean was 84 hours (2014: 57).

The results for term-time weekday opening indicate that there has been a significant increase in the number of libraries open for longer, a significant increase in the number providing 24 hour access to print collections, and a marked increase in the number of libraries opening for more than 100 hours per week. Moreover, the median and average vacation opening hours significantly increased on 2014 as well.

All 95 respondents gave details of term-time weekend opening. Three did not open on Saturdays (2014:2). The number of institutions opening on Sundays increased slightly. In $2016,94.7 \%$ of institutions opened as compared with $94.5 \%$ of institutions in 2014 . In previous years the incidence of term-time Sunday opening used to vary between types of institution. However in 2016 and in 2014 there is no gap between old and new universities: $98 \%$ of old universities, $98 \%$ of new universities opened on Sundays. The results for termtime weekend opening in 2015/2016 indicate continued extensions in opening hours. 
Information was sought on the time at which the law library closed in a standard term-time week, Monday to Thursday. This information was first sought in the 2002 survey. Ninety five respondents provided this information this time. 43 libraries, comprising 17 old universities and 26 new universities, stated they provided 24 hours access during these days (2014: 29 , comprising 12 old universities and 17 new universities). Of the remaining 52 libraries, 10 or $10.5 \%$ closed at $10 \mathrm{pm}$ and 3 or $3 \%$ at $9 \mathrm{pm}$. 17 libraries or $18 \%$ closed at midnight. The earliest closing time was still 7pm (2014: 7pm) and the latest closing time (aside from libraries which opened 24/7) was still 2.30am (2014: 2.30am). The median time was 11pm (2014: $10.30 \mathrm{pm})$.

Not all facilities are necessarily available throughout opening hours. To help provide an indication of key opening hours respondents were asked to indicate the number of hours during a term-time week when a staffed book loan service was available for law items. Eighty nine institutions responded. For these 89 respondents the mean was 62.91 hours (2014: 62.4 hours). The median was 70 hours (2014: 69 hours). The range was 0 hours to 112 hours (2014: 0 hours to 96.5 hours). Twelve institutions (6 old and 6 new) reported that there was no staffed issue service and they were entirely reliant on self-service for issuing materials. This is 3 more than in 2014 ( 9 institutions, 2 old and 7 new).

This year, the survey results for the availability of a staffed book loan service show a slight increase in the average number of hours for which this service was available to patrons but also an increase in the number of institutions with no staffed issue service.

As in previous years we asked whether respondents provided a self-issue system for use with items from the law collection. For 2016, 96\% (2014, also 96\%) said they did provide self-issue facilities.

94 respondents $(97 \%)$ indicated the number of hours during term-time weeks that a reader enquiry service for law was provided by professionally qualified staff. Hours when professional staff could only offer a service of referral onto a law specialist were to be excluded. Six respondents did not provide a reader enquiry service for law (2014: 5). For the remainder, the mean number of hours for which an enquiry service was available was 34.7 hours (2014: 37.8 hours) and the median was 37 hours (2014: 37 hours). The range was 0 to 78.5 hours (2014: 0 to 79 hours). $60 \%$ of respondents provided an enquiry service for between 35 and 40 hours per week (2014: 57\%).

Therefore in 2016 there was a very slight decrease in the average number of hours a reader enquiry service for law was provided and an increased concentration of availability within the range of 35 to 40 hours a week.

\section{Reciprocal borrowing schemes}

As in 2014 we asked about membership of reciprocal borrowing schemes. 95 (or 98\%) respondents provided details. Eighty six respondents (90.5\%) were members of SCONUL Access (2014: 88\%).

$9(9.5 \%)$ were members of SCONUL RX (2014: 12\%).

$21(22 \%)$ were members of regional schemes (2014: $36 \%)$.

$6(6 \%)$ were members of other schemes (2014: $7 \%)$ providing specialised reciprocal borrowing or access arrangements with other institutions. The ACLID and INSPIRE schemes were mentioned.

\section{Distance learning}

At the request of the Society of Legal Scholars (SLS) we again asked questions this year about special support provided by the law library for distance learning courses. As has been 
noted in section 5 , above, only 29 or $30 \%$ of respondents (2014: 26 or $29 \%$ ) offered this type of course.

Five of these institutions ( 2 old universities and 3 new universities) had made arrangements for their distance learning students studying law to have access to a physical (not electronic) law library other than at the institution where they were registered and outside the national reciprocal borrowing schemes mentioned in section 10 above. 9 institutions (2 old university and 7 new universities) provided no additional support other than reciprocal borrowing arrangements.

Twenty institutions provided additional support to distance learners other than that already described (2014: 23 institutions). 14 or $61 \%$ (2014: 17 or $65 \%$ ) provided postal loans, 14 or $61 \%$ (2014: 17 or $65 \%$ ) a phone/e-mail/fax legal research enquiry service, 12 or $52 \%$ (2014: 13 or $50 \%$ ) provided postal delivery of photocopying (subject to copyright), 5 or $22 \%$ (2014: 3 or $12 \%$ ) undertook database searches by library staff on behalf of the distance learning students and 1 or $4 \%$ (2014: 7 or $27 \%$ ) provided study packs. Also mentioned, by 8 respondents (2014: 2) was extended loan periods, access to the "law trove" ebook service, information literacy skills delivered in person at residential weekends and the VLE.

Sixteen respondents or 55\% (2014: 20 or $77 \%$ ) offered a package incl6uding more than one of the services noted.

Some further questions probed the nature of the additional services a little deeper. Twenty eight or $97 \%$ of institutions (2014: 100\%) offering law by distance learning provided access for learners outside the campus to databases and learning materials. All 29 or $100 \%$ (2014: $100 \%$ ) also used a virtual learning environment (VLE) for the delivery of law distance learning courses. All 29 of these institutions provided details of how to access law library materials (by which was meant the law and commentary on it) through the VLE. Respondents were asked to include as many means of access as applied.

Twenty four or $83 \%$ (2014: 23 or $89 \%$ ) provided a link to the library catalogue, 27 or $93 \%$ (2014: 24 or $92 \%$ ) provided links to full text online subscription databases, 18 or $62 \%$ (2014: 19 or $73 \%$ ) scanned full text material into the VLE, and 6 or $21 \%$ used Talis Aspire / REBUS / online reading list software to access digitised readings. One respondent a piece mentioned: core readings via VLE; A-Z and subject lists of databases; links to journals and training materials on how to find and use resources.

Twenty nine or $100 \%$ (2014: 25 or $96 \%$ ) of institutions provided more than one means of access, with 18 or $62 \%$ (2014: 17 or $65 \%$ ) providing all three suggested means of access on the questionnaire: a link to library catalogue, a link to full text databases and a link to full text materials scanned into the VLE.

\section{Legal Databases}

Contrary to the rest of the questionnaire, respondents were asked to indicate their legal database subscriptions at the present time, rather than in the year 2015/2016. The results below therefore show the position in February 2017.

As in recent years, all respondents gave details of subscription databases used in connection with the teaching and research work of the law school. The ten most frequently mentioned law databases are displayed in the graph below. 


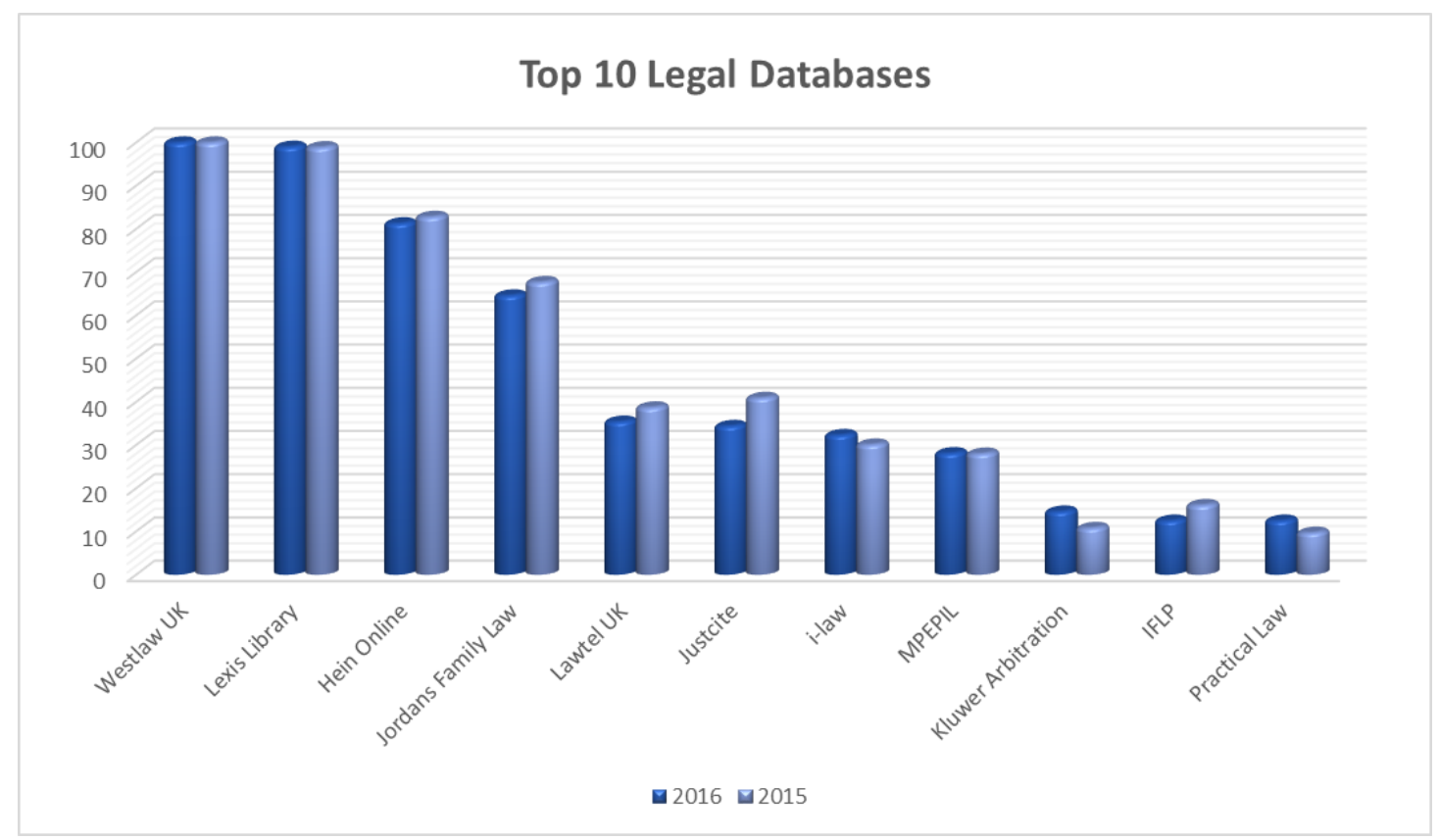

Graph 2: Top 10 legal databases

The law databases' academic market is still fluid but much less so than several years ago and generally very similar to last year. On a positive note, $9 \%$ of respondents ( $8 \%$ last year) were planning new subscriptions before the end of July 2017 . However on the negative side, $14 \%$ (10\% last year) noted planned or recent cancellations before the financial year end.

Like last year, a small number of law databases continue to dominate the market. According to the snapshot survey results using exactly the same survey questions format as in the previous year, in February 2017 Westlaw UK was taken by 96 respondents (100\%) and Lexis $\AA$ Library was taken by 95 of respondents $(99 \%)$. Last year Westlaw UK was also taken by $100 \%$ of respondents and Lexis ${ }^{\circledR}$ Library was taken by $99 \%$. HeinOnline, kept the third position it first gained in 2007 being taken by 78 or $81 \%$ of respondents (last year: 83\%). Jordan's Family Law Online remained in fourth place with 62 or $65 \%$ of respondents $(68 \%$ last year).

Of the other popular databases mentioned by respondents, Lawtel UK moved up to fifth place with $35 \%$ of respondents (39\% last year) and Justcite dropped one place to sixth place with $34 \%(41 \%)$. i-law remained in seventh place with $32 \%$ of respondents (30\% last year) and the Max Planck Encyclopedia of Public International Law remained in eighth place with $28 \%$ of respondents (28\% last year). Kluwer Arbitration moved up to ninth place with 14 or $15 \%$ of respondents (11\% last year). IFLP and Practical Law were both in tenth place with $13 \%$ of respondents.

Looking at the returns for Westlaw in more detail, no cancellations and no new subscriptions were planned, although one respondent was considering subscribing to Westlaw e-books. Two respondents reported that they already subscribed to Westlaw China, four reported they subscribed to Westlaw e-books, one reported that they subscribed to IDS Brief and one reported they subscribed to Westlaw Australia.

Seventy six respondents or $79 \%$ subscribed to Westlaw International (76\% last year) as well. Eight respondents subscribed to Westlaw IE (Irish Law). Four were based in the Irish Republic, one was from Northern Ireland and three were from the UK mainland.

Respondents were asked to indicate the subscriptions they took to particular parts of the

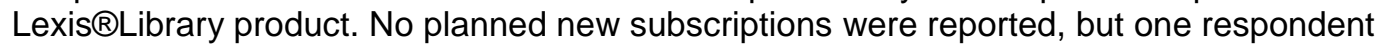
reported that they were planning to cancel their subscription to Lexis PSL. 
The Cases module and the Legislation module were the most popular products, both taken by $95 \%$ of respondents. The Journals module was taken by $94 \%$ of respondents. Halsbury's Laws was taken by $85 \%$ of respondents and Newspapers on Lexis by $69 \%$, whilst the International Materials module was taken by $67 \%$ of respondents. The Encyclopaedia of Forms and Precedents in electronic format was taken by $59 \% .16$ respondents or $17 \%$ took Lexis PSL.

32 respondents ticked "other Lexis®Library products" in the survey questionnaire. However most did not specify specific products so it is difficult to give a safe popularity percentage split between the other Lexis ${ }^{\circledR}$ Library products, other than to say that the following products were specifically mentioned by many respondents: Academic Scotland Online, Accountancy lite, Atkins Court Forms, Family, Harvey's on Industrial Relations and Employment Law, Hill \& Redman: Landlord and Tenant, Legal Alerter, Legal Practice area, Litigation, Local Government, Personal Injury, Property, Smart Forms, Tolleys Tax, Valentines on Northern Ireland law and Wills,

Two respondents stated that they subscribed to LexisNexis®Juris Classeur and two respondents took Lexis Middle East Law as standalone products.

HeinOnline retained its third position with a slightly lower percentage, being taken by 78 or $81 \%$ of respondents (last year: $83 \%$ ). One respondent reported that they were considering subscribing to HeinOnLine, but one reported they planned to cancel their subscription because it was "less essential" than other databases.

Jordan's Family Law Online remained in fourth place with 62 respondents or $65 \%$ (63 or $68 \%$ last year). One respondent reported plans to subscribe to Jordan's before July 2017, but one respondent reported plans to cancel their subscription.

Lawtel UK took fifth place with $35 \%$ of respondents taking the database (39\% last year). However three respondents reported plans to cancel their subscription because of "low usage".

Justcite took sixth place with $34 \%$ of respondents ( $41 \%$ last year). In addition two respondents were planning to subscribe to Justcite before $31^{\text {st }}$ July 2017 and one was planning to cancel because prices had increased.

Other than the databases already discussed in detail, the following databases were mentioned by $10 \%$ or more respondents:

$\begin{array}{lrrr} & \begin{array}{r}2017 \\ \text { Institutions }\end{array} & \begin{array}{r}2017 \\ \%\end{array} & 2016 \\ \text { i-Law } & 31 & 32 \% & 30 \% \\ \text { Max Planck Encyclopedia of PIL } & 27 & 28 \% & 28 \% \\ \text { Kluwer Arbitration } & 14 & 15 \% & 11 \% \\ \text { Index to Foreign Legal Periodicals } & 12 & 13 \% & 16 \% \\ \text { Practical Law } & 12 & 13 \% & 10 \% \\ \text { Index to Legal Periodicals } & 11 & 12 \% & 14 \%\end{array}$

Databases cited by 3 or more respondents included Oxford Reports on International Law, Oxford Public International Law and Lawtel EU (each with 6 respondents). Oxford Scholarship Online, Beck, Investment Arbitration Reporter and Recueil des Cours (each with 5 respondents). OGEL - Oil, Gas and Energy Law and Investor State Law Guide (both 4 respondents). IBFD, Kemp on Lawtel, Trade Law Guide and World Trade Law.net (each with 3 respondents). 
In total 22 respondents (or $23 \%$ ) subscribed to Justis products other than Justcite. Although not all respondents gave full details of their Justis subscriptions the following limited information was reported: 5 respondents each subscribed to UK legislation and International Law Reports (ILR), 4 respondents subscribed to Irish Reports, 3 respondents subscribed to Case Law and 2 each to EU, Sessions Cases and State Trials. One respondent each subscribed to "All", BLISS, Caribbean Law Reports, OPIL, Parliament, Singapore Law Reports and TLR.

Databases of European legal information continued to be casualties in the changing academic legal database market. Eurolaw was subscribed to by 2 respondents.

The median number of legal database subscriptions taken in responding libraries in February 2017 was 6 (February 2016: 7) and the average number was 8 databases (February 2016: 8). The numbers of legal databases offered by institutions ranged from 1 to 49 ( 1 to 57 last year).

\section{Other databases}

In addition to law databases, law schools use a range of more general information databases such as the newspapers which are of relevance to students in a wide range of disciplines. Eighty six respondents (89\%) noted other subscription databases which contribute significantly to the teaching and research work of their law school. This shows a one percentage decrease from the $90 \%$ recorded last year.

JSTOR was again the most widely used general database with 65 or $67 \%$ of respondents (63 or $68 \%$ last year). House of Commons Parliamentary Papers (HCPP) was mentioned by 61 or $63 \%$ of respondents (60 or $65 \%$ last year) and gained second place. Third was EBSCO Business Source with 56 or $58 \%$. Fourth was ISI Web of Science with 53 or $55 \%$. Fifth was EBSCO Academic with 30 or $31 \%$. ASSIA with 29 or $30 \%$ was sixth and Criminal Justice Abstracts at 27 or $28 \%$ was seventh. The following databases were used by fewer than $10 \%$ of respondents: SCOPUS was used by 9 or $9 \%$ of respondents; Science Direct (5 or $5 \%$ of respondents); and Proquest dissertations and theses was used by 4 or $4 \%$ of respondents. The following databases were mentioned by 3 respondents each: $\mathrm{ABI} / \mathrm{Inform}$; Emerald; FT.com; IBSS; and Project Muse. A further 36 non-law subscription databases were mentioned no more than twice.

By February 2017,62 or $64 \%$ of respondents used a web-based combined newspaper database to access the full range of newspapers (62 or $67 \%$ last year), although not every respondent specified a particular database and many respondents subscribed to more than one database. In addition many respondents had subscriptions to the archives of individual newspaper titles. Taking into account all those respondents who did specify particular databases, the top two suppliers were again Nexis UK used by 30 respondents (35 last year) and Proquest with 17 respondents (18 last year). Factiva was taken by 5 respondents ( 6 last year) and Gale NewsVault was taken by 3 respondents ( 6 last year). Gale Infotrack, Newsbank and UK Press Online were each taken by 2 respondents. The following databases were mentioned once a piece: Academic Onefile; Access World News; British newspapers archive; Irish newspaper archive; Infotrac; International newsstand; JISC FE custom news; State papers and Times digital archive. The results for this year indicate the continued popularity of Nexis UK and Proquest. Otherwise the results show only slight changes in the popularity of subscriber newspaper databases used to contribute significantly to teaching and research in the law school.

\section{E-journals and e-books}

Every other year since 2004, we have asked questions about electronic journals and books. We repeated the same questions as used in 2014, to try to gauge the impact electronic materials are having on print subscriptions. 
Eighty two, or $87 \%$ of respondents (2014: $76,87 \%$ ) said they subscribed to an electronic journal database which includes law titles, excluding Lexis $®$ Library, Westlaw UK, HeinOnline, e-journal gateways (e.g. SwetsWise) and special deals (e.g. NESLI). The pattern across different types of institution showed a slightly reduced take-up amongst old universities and an increased take-up amongst new universities on 2014. Forty were old universities (2014: 42), 40 were new universities (2014: 31) and 2 (2014:3) were other types of institution.

However, as a result of subscribing to law e-journal databases 39 , or $48 \%$, of those with access had cancelled a print subscription to a law journal (2014: 30 or $40 \%)$. Twenty four old universities (2014: 17), 15 new universities (2014: 12) and 0 other institutions (2014: 1) had replaced a law journal print subscription with electronic access.

A similar number of institutions: 37 or $39 \%$ of respondents (2014: 37 or $48 \%$ ) said they had cancelled subscriptions to the print version of law material during the current year where the same resource was available electronically. They were 19 old universities, 16 new and 2 other types of institution.

As in previous years we sought more information about the impact electronic subscriptions were having on print subscriptions. Were institutions starting to cut specific print subs when the same material was available electronically? Which types of print publication were being cut? Were there differences in the cuts made by the different types of institution?

Thirty three institutions (2014: 27) provided details of the titles of print materials they had cancelled where the same material was available electronically. They comprised 17 old institutions, 14 new and 2 other. A further 5 respondents (2014: 4) said there were too many titles to list or they did not have the information. Of those who sent lists 5 mentioned more than 10 publications (some considerably more) and 7 had lists of between 5 and 10 titles.

Excluding instances where respondents said they were cancelling duplicate subscriptions to leave only a single subscription, a total of 153 print titles were cancelled (2014: 159). That number excludes five vague answers (2014: 4), All this adds up to a substantial number of cancellations in one year, although perhaps fewer overall than was recorded in previous years leading one to speculate that the number of print cancellations in favour of an electronic alternative may have reached a plateau for the time being.

In 2016 the cancellations axe fell almost entirely on print law journals and law reports. Of the 153 specifically mentioned cancelled print titles, 109 were law journals and 33 titles were law reports. Looking only at journals, old universities mentioned 50 titles which had been cancelled, whilst new universities mentioned 58 cancellations and other institutions mentioned 1 title. Fewer print law report titles were cancelled: 14 by old universities, 18 by new universities and 1 by other institutions. The titles cancelled included both core and specialised titles. The remaining cancelled print titles were mainly loose-leaf works, digests and practitioner works.

In summary, this snapshot of cancellations indicates that the priority for cancellation appears to remain with law journals and law reports including, though not exclusively, those available electronically.

We asked two questions to gain an impression of which parts of the law collection had sustained cuts and why. Of the 61 respondents who reported cuts, 20 or $33 \%$ reported the cuts falling more heavily on domestic law materials, 22 or $36 \%$ falling equally on UK and foreign, comparative and international (FCIL) materials; and 19 or $31 \%$ more heavily on FCIL materials.

Forty of the 61 respondents gave reasons for where the cuts fell, some citing different factors. The most frequently cited (12 times) was the availability of materials in electronic format, resulting in the cancellation of print subscriptions. Second most frequent (10 times) was that the cuts had to fall on UK materials because there were either, very few or no FCIL materials held. And thirdly 7 institutions said the reason was low usage rather than jurisdiction. Other 
reasons mentioned were "needing to focus on international law for their LLM programmes" and "maintaining a balance of teaching materials".

As in previous years we asked about subscriptions to e-book publishers. Ninety four respondents (2014: 90$)$ listed the e-book publishers to which they subscribed for law titles. They were 42 old universities and 49 new universities and 3 other types of institution.

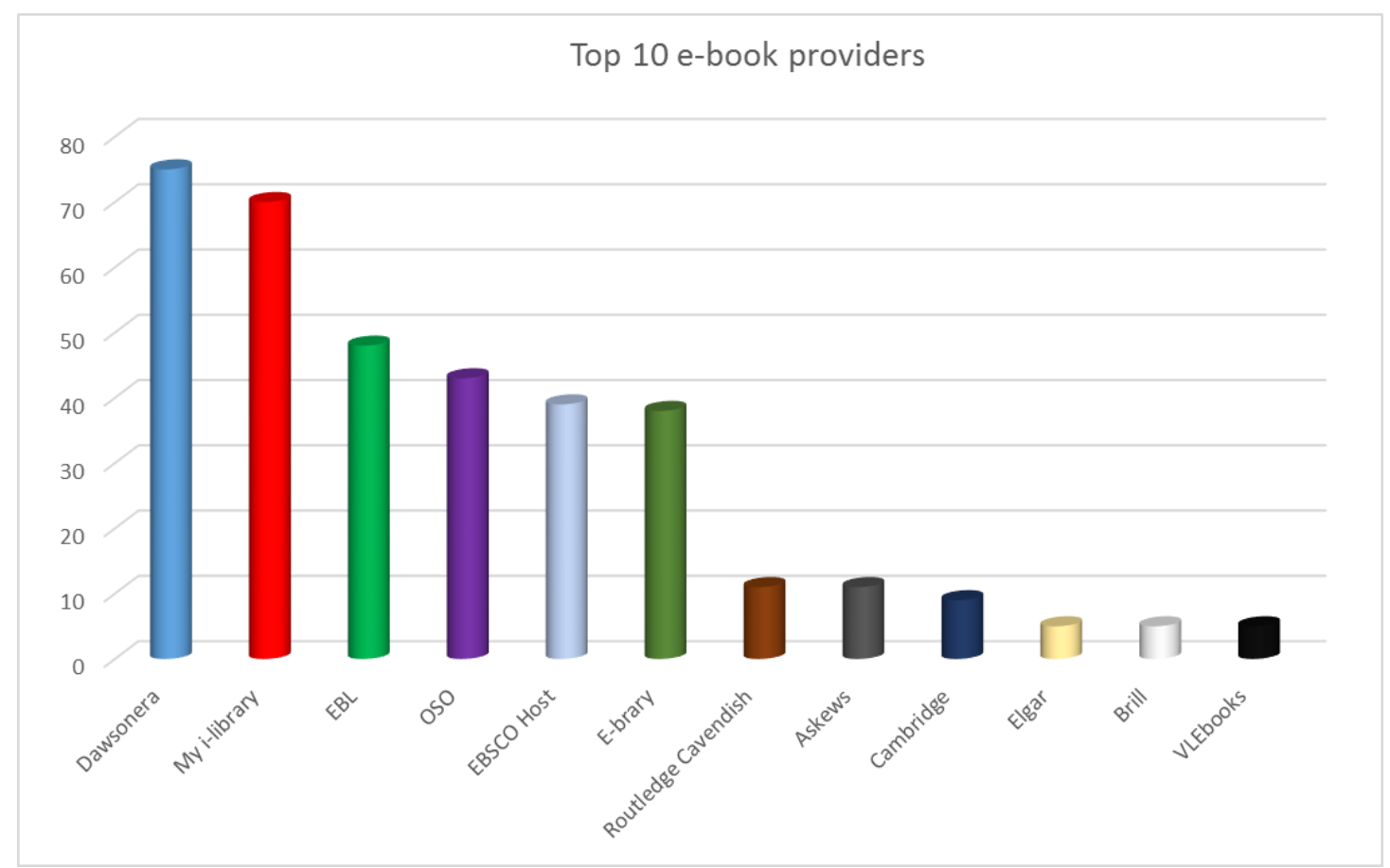

Graph 3: Top 10 e-book publishers

As the graph above shows, 75 subscribed to Dawsonera (2014: 71), 70 subscribed to My-ilibrary (2014: 66), 48 to EBL (2014: 38), 43 to OSO - Oxford Scholarship Online (2014: 38), 39 to EBSCO host (2014: 46), 38 to E-brary, 11 each to Routledge Cavendish and Askews, and 9 to Cambridge e-books (2014: 5). Finally, 5 each to Brill, Elgar and VLEbooks.

Westlaw ebooks were taken by 4 institutions, Hart by 3, and T\&F and Ebook Central by 2 each. A further 9 niche products were taken by just one library.

15

\section{Expenditure}

Eighty five of the 97 libraries (or $88 \%$ of respondents) were able to provide total expenditure figures for 2015/2016. Those respondents who did not respond either could not disaggregate law expenditure from other subjects or were not prepared to provide the information.

\subsection{Total expenditure on law materials}

Total expenditure on the acquisitions of law materials ranged from $£ 9,449$ to $£ 1,305,000$ (2015: $£ 13,476$ to $£ 1,283,906)$. Mean expenditure was $£ 171,073$ (2015: $£ 184,874)$, a $7.46 \%$ decrease on 2015. This decrease in expenditure on 2015 (following on from a 1.02\% decrease and a $2 \%$ increase in previous years) is of concern, although to sound a note of caution the decrease may be partly a reflection of the changing pool of survey respondents.

It is helpful in understanding these changes to compare the expenditure in the different types of institution.

Old universities: 38 out of a possible 43 responses (2015: 41 out of 44$)$. 
Range from $£ 16,666$ to $£ 776,000$; median $£ 159,867$ (increased by $3.17 \%$ on 2015); mean $£ 195,837$ (increased by $0.85 \%$ on 2015). $75 \%$ of old universities spent at least $£ 100,718$ (down $15.8 \%$ on last year). $25 \%$ spent more than $£ 247,672$ (down $2.9 \%$ on last year).

New universities: 44 out of a possible 51 responses (2015: 44 out of 46).

Range $£ 29,577$ to $£ 1,305,000$; median $£ 104,900$ (down $8.62 \%$ on last year); mean $£ 159,232$ (down $12.88 \%$ on last year). $75 \%$ of new universities spent at least $£ 65,237$ (down $8.3 \%$ on last year) and $25 \%$ spent more than $£ 156,834$ (down $12.3 \%$ on last year).

Other institutions: 3 responses (2014: 3 )

This sample is too small to be meaningful or anonymous.

Based on the means, these results seem to indicate that expenditure on law materials has very slightly increased in old universities, but has decreased markedly in new universities.

For each law student in a typical university (looking at the median) £192 was spent on law materials. This is a small 3.07\% decrease on the figure for 2015 .

However, the rate of increase has not been evenly distributed across the higher education sector. In an old university, median spend per student was lower at £185 (2015: £196) and for a student in a new university the median was also lower at £197 (2015: £207), creating a slightly wider gap between old and new universities of $6.37 \%$ (2015: $5.34 \%)$. It is also important to state that the median spend per student continues to be higher at new universities than at old universities for the second year. In other types of institution the median spend per student was $£ 162$ (2015: $£ 341$ ). As graph 5 illustrates, the gap between old and new universities fluctuates over time but slightly widened in 2015/2016 due to a decrease in median expenditure in old universities and a smaller decrease in the median for new universities. Per capita expenditure at other types of institution reduced substantially. However this marked statistical change is due to the very tiny sample and should be used with caution.

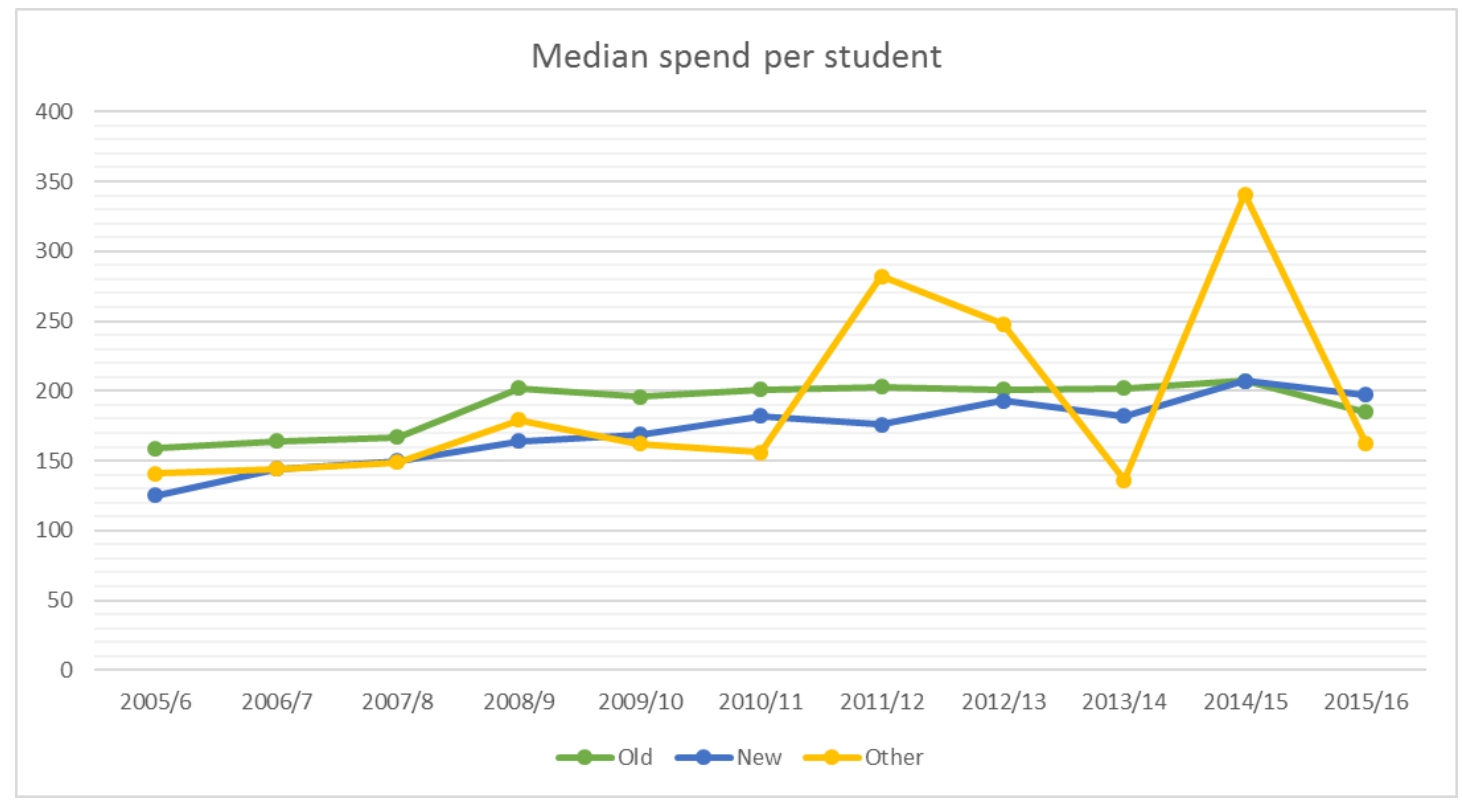

Graph 4: Library materials expenditure per student

Taking the mean, rather than the median, the pattern is the same but with a wider gap between sectors. This year the mean spend per student at new universities has overtaken the mean spend per student at old universities. Mean law materials expenditure per student in old universities was $£ 205$, down $18.58 \%$ from 2015 whereas in new universities it was $£ 232$, down $7.2 \%$ on 2015. In other types of institution the mean spend per student was £205 (2015: 
£341), indicating a steep decrease, but these results have been calculated over a very few respondents and should be treated with caution.

\subsection{Monograph expenditure}

Seventy four respondents provided details of spending on books, three fewer than last year. Some respondents had difficulty providing a discrete and accurate figure for law expenditure alone owing to the way the university or college budget is divided amongst subject areas.

Expenditure on monographs ranged from 1,877 to 290,940 (2015: $£ 3,020$ to $£ 251,703$ ), with a mean of $£ 38,659$, a decrease of $10.4 \%$ on 2015 and a median of $£ 27,521$ a decrease of $14.7 \%$ on last year.

In 2016, on average, monograph acquisitions accounted for $23 \%$ of total law material expenditure (2015: 22\%; 2014: 22\%; 2013: 21\%; 2012: 21\%). The proportion of total expenditure spent on books ranged from $6 \%$ to $55 \%$ with a median of $22 \%$ (2015: $6 \%$ to $59 \%$ with a median of $20 \%$ ).

Analysed by type of institution the figures for monograph expenditure were:

Old universities: 32 respondents (2015: 36 )

Range $£ 4,519$ to $£ 115,000$; median $£ 41,898$, an increase of $11 \%$ on last year; mean $£ 45,793$ an increase of $5 \%$ on 2015 . Mean of $24 \%$ of total law material expenditure (2015: $23 \%$ ).

New universities: 39 respondents (2015: 39)

Range $£ 2,465$ to $£ 290,940$; median $£ 22,000$, an increase of $3.9 \%$ on last year; mean $£ 35,234$, a decrease of $20.7 \%$ on last year. Mean of $22 \%$ of total law material expenditure (2015: 21\%).

Other institutions: 3 institutions (2015: 2 )

The range, median and mean figures are not very useful because of the tiny sample. Mean of $17 \%$ of total law material expenditure (2015: $24 \%)$.

The mean figure for old universities showed a increase of $5 \%$ in expenditure on monographs, whilst the mean figure for new universities showed a substantial decrease of $20.7 \%$. The percentage of total law expenditure devoted to monographs has increased very slightly for both old and universities. Please note that these figures may be partly a reflection of the changing pool of survey respondents.

\subsection{Serials expenditure}

Seventy four of respondents who gave any financial figures were able to provide a figure for their spending on serials, the same number as last year. The questionnaire defined serials as law journals, statutes, law reports and loose-leaf updates.

As a mean, serials accounted for $37 \%$ of total law materials expenditure (2015: $40 \%)$. The proportion of expenditure given to serials ranged from $6 \%$ to $73 \%$ (2015: $9 \%$ to $75 \%$ ) with a median of $35 \%$ (2015: $41 \%$ ). Overall, serials expenditure ranged from $£ 1,732$ to $£ 565,600$ (2015: $£ 3,334$ to $£ 560,000)$, with a median of $£ 40,828(2015: £ 54,253)$ and a mean of $£ 72,467$ (2015: £83,745).

Analysed by type of institution the figures were:

Old universities: 32 responses (2015: 34$)$

Range $£ 3,085$ to $£ 565,600$; median $£ 69,642$, down $2.7 \%$ on last year; mean $£ 101,052$, up by $2.4 \%$ on last year. Mean of $41 \%$ of total law material expenditure (2015: $44 \%$ ).

New universities: 39 responses (2015: 38) 
Range $£ 4,278$ to $£ 352,087$; median $£ 30,004$, down $33.5 \%$ on last year; mean $£ 53,425$, down $27.7 \%$ on last year. Mean of $33 \%$ total law material expenditure (2015: $38 \%$ ).

Other institutions: 3 responses (2015: 2)

The range, median and mean figures are not very useful because of the tiny sample. Mean of $42 \%$ of total law material expenditure (2015: $36 \%)$.

The percentage of total law expenditure devoted to serials has continued to fall for both old and new universities. Please note that these figures may be partly a reflection of the changing pool of survey respondents.

\subsection{Database expenditure}

Databases accounted for $40 \%$ of total law materials expenditure in the mean, ranging from $11 \%$ to $82 \%$ with a median of $39 \%$ (2015: $38 \%$ of total law materials expenditure in the mean, ranging from $11 \%$ to $78 \%$ with a median of $35 \%$ ). Of the 71 responses (2015: 74), expenditure ranged from $£ 4,926$ to $£ 869,000$ (2015: $£ 6,944$ to $£ 808,955)$ with a median of $£ 42,865(2015: £ 44,474)$, a fall of $3.6 \%$ on last year, and a mean of $£ 66,511(2015: £ 67,533)$, a decrease of $1.5 \%$ on last year.

Analysed by type of institution the figures were:

Old universities: 30 respondents (2015: 34 )

Range $£ 22,562$ to $£ 174,543$; median $£ 54,074$, an increase of $6.3 \%$ on last year; mean $£ 63,881$, up $7.9 \%$ on last year. Median $33 \%$ and mean $34 \%$ of total law material expenditure (2015: $29 \%$ and $33 \%$ ).

New universities: 39 respondents (2015: 38)

Range $£ 14,636$ to $£ 869,000$; median $£ 36,946$, down $2 \%$ on 2015 ; mean $£ 71,266$ down $8.4 \%$ on last year. Median $40 \%$ and mean $44 \%$ of total law material expenditure (2015: $39 \%$ and $42 \%)$.

Other institutions: 3 respondents (2015: 2)

The range, median and mean figures are not very useful because of the tiny sample. Median and mean both $41 \%$ of total law material expenditure (2014: both $40 \%$ ).

Median and mean spending on databases in old universities has increased on last year, whereas median and mean spending on databases in new universities has slightly decreased on last year. The median and mean percentages of total law expenditure devoted to databases has continued to increase for old and new universities. Please note that these figures may be partly a reflection of the changing pool of survey respondents.

\subsection{E-book expenditure}

Thirty two respondents provided details of spending on e-books (27 last year). It is important to point out that more respondents probably purchase e-books, but that they were not all able to provide discrete and accurate figures for this law expenditure alone owing to the way the university or college budget is divided amongst subject areas. As a consequence the following e-book expenditure figures should be treated with some caution, but they are of interest nevertheless.

Expenditure on e-books ranged from $£ 933$ to $£ 103,461$, with a mean of $£ 14,759$ and a median of $£ 8,751$.

Analysed by type of institution the figures for e-book expenditure were:

Old universities: 17 respondents (2015: 12)

Range $£ 1,000$ to $£ 42,818$; mean $£ 14,676$; median $£ 10,734$. 
New universities: 15 respondents (2015: 15)

Range £933 to £103,461; mean £14,854; median £6,987.

Other institutions: 0 institution (2015: 0)

No data to calculate figures.

\subsection{Other expenditure on law materials}

Thirteen respondents noted "other" expenditure, the same as last year. This is a small sample. Expenditure ranged from $£ 100$ to $£ 152,129$ (2015: $£ 100$ to $£ 47,020$ ), with a median of $£ 6,643$ (2015: $£ 3.072)$ a $116 \%$ increase, and a mean of $£ 24,526(2015: £ 9,760)$ an increase of $151 \%$.

Only 2 respondents specified what the "other" expenditure was spent on: one stated "ILL" and one stated "Standing Orders".

\subsection{Expenditure by institutions not providing vocational or professional award courses}

At the suggestion of one respondent we have carried out some analyses on expenditure by those institutions which offer only an exempting law degree or LLM courses, that is, do not offer vocational courses, such as the LPC, BPTC, Diploma in Professional Legal Practice (Scotland) or Professional Practice Course (Ireland) or Degree of Barrister-at-law (Ireland) or courses leading to professional awards, such as the CPE, CILEx or Council for Licensed Conveyancers. These institutions believe that vocational courses require the purchase of expensive practitioner materials and so the results given earlier in section 15 are inflated and make comparison with their situation very difficult. So, we have re-run the analyses for total expenditure.

Total expenditure on the acquisition of law materials ranged from $£ 10,391$ to $£ 776,000$ (2015: $£ 29,826$ to $£ 745,600)$. Mean expenditure was $£ 143,999$ (2015: $£ 159,923)$, a 9.96\% decrease on 2015 . To sound a note of caution the results are probably partly a reflection of the changing pool of survey respondents.

It is helpful in understanding these changes to compare the expenditure in the different types of institution.

Old universities: 31 respondents, 29 provided financial data $(2015: 29,28)$ provided financial data)

Range £16,666 to $£ 776,000$ (2015: $£ 35,063$ to $£ 745,600$ ); median $£ 148,902$ (2015: $£ 169,311)$, a $12.05 \%$ decrease on last year; mean £197,417 (2015: $£ 204,322$ ), a 3.38\% decrease on last year.

New universities: 25 respondents, 23 providing financial data (2015: 23, 23 provided financial data)

Range 229,577 to $£ 185,037$ (2015: $£ 29,826$ to $£ 504,628$ ); median $£ 72,692$ (2015: $£ 74,000$ ), a decrease of $1.77 \%$ on 2015 ; mean $£ 197,417$ (2015: $£ 109,886)$, a sizable $24.96 \%$ decrease on last year.

Other institutions: 1 respondent and I providing financial information $(2015: 2,1)$

Comparing these results with those in paragraph 15.1 for all respondents, there are differences between the medians and means in old universities, but much more significant are the differences between the medians and means amongst new universities. The reason for the differences lay in the numbers of students at each institution - those new universities which do not offer vocational courses have generally smaller numbers of students than those 
new universities that do, hence a smaller expenditure on the acquisition of library materials. This distinction is less marked at old universities.

\section{Sources of income}

Eighty four (2015: 87) respondents gave details of the source of the funds from which law material expenditure was met.

The greatest proportion of acquisitions was funded from general library funds, and all but one institution responding received at least part of their income this way. Using the mean, $90 \%$ of old universities', $94 \%$ of new universities' and $100 \%$ of other institutions' income for law library materials was from general library funds $(81 \%, 91 \%$ and $100 \%$ last year). When the median is used the figures are $100 \%, 100 \%$ and $100 \%$ (2015: $92 \%, 100 \%$ and $100 \%)$. The increase in the mean percentage for old and new universities indicates an increased focus on general library funds.

Law schools contributed to funding the acquisition of law materials in 26 institutions (2015: 35 ). As has been noted in previous survey reports, a majority of law schools make no such contribution at all (69\% this year, $60 \%$ in 2015$)$. This fact is reflected in the fact that, only $45 \%$ (2015: $50 \%$ ) of old university law schools, $21 \%$ (2015: $28 \%$ ) of new university law schools and 0\% (2015: $0 \%$ ) of other institutions' schools contributed something.

Of the law schools that contributed, the amount ranged from $£ 3,952$ to $£ 372,650$ (2015: $£ 2,500$ to $£ 254,951$ ). The median contribution was $£ 18,553$, an increase of $27.3 \%$ on last year. The mean was $£ 45,044$, up $3.8 \%$ on last year.

For the libraries that received funds from the law school, these funds represented a mean of $26 \%$ of the total income for the purchase of law materials, with a median of $18 \%$ ( $24 \%$ and $14 \%$ last year). This year the mean percentage contributions by law schools based in old and new universities widened with old universities contributing a higher mean percentage than new universities. Of the old university law schools who contributed anything, the mean contribution represented $23.07 \%$ of the funds for library materials (2015: $20.5 \%$ ), while new university law schools contributed more at $32.65 \%$ (2015: $29 \%$ ). No 'other' institutions received funds from the law school (2015: 0\%).

In the old universities, median law school funding for law materials was $£ 17,105$, up $32 \%$ on last year. The mean was $£ 54,996$, up by $40 \%$ on last year. In new universities the comparative figures were a median of $£ 20,000$, down by $11 \%$ on last year and a mean of $£ 26,255$ down by $48 \%$ on 2015 .

In summary for law school contributions: over two-thirds of all law schools $(69 \%)$ make no contribution to funding the acquisition of law materials. However there was an increase in the old University law schools' average contribution (at 23.07\%) to the total funds for library materials and an increase in the new university law school's average contribution (at $32.65 \%$ ) to the total funds for library materials.

Seven institutions (2015: 10) reported receiving income from other university budgets for law materials. For these 4 old universities, 3 new universities and 0 other institutions, the amount of income from these sources ranged from $£ 4,250$ to $£ 123,831$ (2015: $£ 2,500$ to $£ 291,326$ ).

One respondent reported funding from user charging (2015: 1).

Finally, 2 institutions (2015: 2) reported receiving financial contributions towards law materials from outside bodies. The sums ranged from $£ 27,100$ to $£ 127,670$ (2015: $£ 27,582$ to $£ 93,479$ ), with a median income of $£ 77,385$ (2015: $£ 60,531)$ and a mean income of $£ 77,385$ (2015:

$£ 60,531)$. These were both old universities. 


\subsection{Targeted funding from the law school}

Two further questions sought to explore whether law schools paid for specific materials or services.

The first question asked respondents to indicate whether specific types of materials were paid for by the law school. 24 respondents (25\%) replied in the positive $(2015: 28,30 \%)$ with some respondents mentioning more than one type of material. By far the most frequently mentioned was payment of, or contributions towards, the cost of electronic databases such as Lexis Library, Westlaw or HeinOnline - 17 respondents (2015: 18). Six respondents noted that the law school contributed towards the cost of law books, journals or reports (8 in 2015) ranging from research journals to specialist monographs to multiple copies of textbooks. Library materials for the Legal Practice Course or Bar Vocational Course were mentioned specifically by 3 respondents ( 3 in 2015).

In the second question in this section, respondents were asked to indicate whether the law school contributed to law library expenditure other than for the purchase of law materials.

Only 4 respondents ( 3 in 2015) received this additional funding. They indicated the total amount of the contribution, ranging from $£ 3,664$ to $£ 47,000$ (2015: $£ 15,000$ to $£ 172,500$ ).

Respondents reported receiving funding towards general staffing costs or the full cost of a law librarian / legal researcher salary or the "additional costs to resource newly proposed modules".

\section{Staffing}

The responses to the questions on staffing provide a picture of the number and qualifications of library staff in academic law libraries. The definition of law library staff provided in the questionnaire was the same as for the previous surveys. To be included in the survey, library staff were to spend $50 \%$ or more of their working time on the care and servicing of the law collection.

Seventeen (or $17.5 \%$ ) of the 97 responding institutions had no staff which met this criterion (2015: 13 or 14\%). Of these, 7 (2015: 8) were old universities and 10 (2015: 5) were new universities. In most instances respondents mentioned that law was just one of a number of subjects for which a team of librarians was responsible, but no one spent the requisite $50 \%$ or more of their time on law alone, or that their responsibilities were diversifying into library-wide activities.

For the 80 respondents (2015: 80 ) with staff who met the criterion, the full-time equivalent (FTE) number of staff ranged from 0.15 to 22.60 (2015: 0.25 to 25.10) with a median of 1.0 (2015: 1.0) and a mean of 2.94 (2015: 2.75). 37.5\% (2015: 36.25\%) had exactly one FTE member of law library staff.

As in previous surveys, old universities ranged most widely in the number of law library staff and $23 \%$ had four or more FTE (2015: $22 \%)$, compared to only $12 \%$ of new universities (2015: 10\%).

The median for old universities' FTE law library staffing was $1.5(2015: 1.0)$ with a mean of 3.6 (2015: 3.45). The median for new universities was 1.0 (2015: 1.0) and the mean was 2.52 (2015: 2.25). The other institutions were varied in their staffing levels, from 0.5 to 1 FTE (2015: 1 to 2).

The staffing figures therefore portray a very slightly better picture for old and new universities than last year.

The overall mean number of staff increased from 2.75 FTE in 2015 to 2.94 FTE in 2016, the mean number of staff for old universities increased from 3.45 FTE in 2015 to 3.6 FTE in 2016, 
and the mean number of staff in new universities increased from 2.25 FTE in 2015 to 2.52 in 2016.

Respondents were asked for the FTE number of staff in professional, clerical and other posts.

\subsection{Professional posts}

Of the 80 institutions which had staff with the care and servicing of the law collections as their sole or principal function, only 2 ( 1 old university and 1 "other" institution) did not have a professional post (2015: 2). Overall, then, of the 80 responding law libraries with staff who met the definition, $97.5 \%$ had a designated professional who could dedicate a significant proportion of their time to the needs of the law service (2015: $97.5 \%)$. The number of professional FTE posts ranged from 0.15 to 7.7 (2015: 0.25 to 10.9) and $41 \%$ of institutions (2015: 44\%) with any professional posts had exactly $1.0 \mathrm{FTE}$.

In old universities, 13 of the 36 respondents had exactly 1.0 professional FTE, with 13 institutions with less than 1.0 professional FTE; 10 had more than 1.0 professional FTE and the maximum was 7.4 professional FTE posts (7.6 in 2015). The mean for old universities was 1.46 professional FTEs (2015: 1.38 FTEs). The results show a very slight increase in the average level of professional staffing in old universities.

In new universities, 19 of the 41 respondents had exactly 1.0 FTE professional post, with 13 institutions with less than 1.0 FTE; 9 had more than 1.0 FTE and the maximum was $7.7 \mathrm{FTE}$ professional posts. The mean for new universities was 1.3 (2015: 1.38 FTE). These results also show a very slight decrease in the average level of professional staffing in new universities. In the 3 "other" institutions, none had exactly 1 FTE, one had less than 1.0 FTE and two had more than 1.0 FTE.

\subsection{Clerical posts}

Turning to clerical posts, 32 institutions out of 80 respondents had clerical staff who met the definition given in section 17 . Of the 48 who had library staff but no clerical staff, 16 were old universities, 30 were new universities and 2 were "other" institutions.

For the 32 institutions that did have clerical staffing, numbers ranged from 0.5 to 14.85 (2015: 0.3 to 17), with median of 1.43 (2015: 0.5 ) and a mean of 3.82 (2015: 3.33). Fifty six percent of old universities reported clerical staff for law as opposed to $27 \%$ of new universities (2015: $53 \%, 29 \%)$.

As found in past years, old universities typically had larger numbers of clerical staff. Six of the 20 old universities with clerical staff had four or more such staff and the mean was 3.67 (2015: 3.81), whereas of the 11 new universities with clerical staff only 4 (2015:2) had four or more such staff.

A partial explanation for the large difference between the presence of clerical staffing in old and new universities could be drawn from the location of the law library. Of the 15 (2015: 14) institutions with more than 2 FTE clerical staff, 7 or $47 \%$ had a law library located separately from other collections (2015: 8 or $57 \%$ ). Of these 7 institutions, 7 (100\%) were old universities. Where there is a separate law library, staffing is less likely to be shared between subjects, and circulation and other activities will be dedicated to the law collections.

\subsection{Staff employed in other posts}

Seven institutions (2015: 8) noted law library staff, other than clerical or professional staff, who met the criterion noted in section 17 above. Of these, 4 were old universities and 3 were new universities. FTE numbers of such staff ranged from 0.5 to 3.0 (2015: 0.21 to 1.0). The duties were specified as "Supervisor post" by one of the seven respondents. 


\subsection{Qualifications of staff}

Respondents were asked to indicate how many of the staff whose principal function was the care of the law collections had a professional librarianship or information science (LIS) qualification or an academic or professional qualification in law.

Seventy-nine respondents or $81 \%$ (2015: 80 or $86 \%$ ) of respondents had at least one member of staff who had a LIS qualification, although for 20 institutions this was less than one full-time member of staff (2015: 24).

Thirty seven (2015: 38) institutions had exactly one FTE member of staff with a LIS qualification and 9 (2015: 8) had three or more FTE staff with such a qualification.

Importantly it is still true to say that there was no unqualified staff in professional posts.

Nineteen of the 80 respondents representing 24\% of institutions (2015: $25 \%$ ) had staff with an academic or professional qualification in law. Twelve (2015: 14) had at least one member of staff so qualified, and 9 (2015: 8) had exactly 1.0 FTE staff member with a law qualification.

As found in past surveys, library staff with law qualifications were much more common in old universities. Looking at only those institutions which had any staff which met the criterion noted in section 17 above, in old universities 36\% (2015: 31\%) of law libraries had law qualified staff, compared to new universities where only 15\% (2015: 22\%) had law qualified staff. None (2015: 0) of the "other" institutions had such staff. Overall, $68 \%$ of the libraries with law qualified staff were in old universities.

\section{The SLS Statement of Standards, 2009}

Two questions were added in 2010 at the request of SLS to gauge how far law librarians were aware of the 2009 Society of Legal Scholars Statement of standards for university law library provision in the United Kingdom and whether they had had occasion to use it in discussions on funding and administration of the law collection in their institution. I can record a small decline in awareness in that that a reduced number of respondents 74 or $78 \%$ (2014: 76 or $84 \%$ ) stated they were still aware of the revised Statement, and a decline in those using the Statement in discussions as only 46 or $47 \%$ of institutions said they used it in 2015/16 (2014: 55 or $60 \%)$.

\section{The future}

Since 2004 and every other year since, we asked for the personal views of respondents on the changes they envisage over the next five years to the provision of legal information within their library. We repeated the questions this year.

\subsection{Electronic v Paper}

Ninety five (98\%) of respondents (2014: 90 or $99 \%$ ) gave their views on the balance of provision between electronic and paper access to legal information. 53\% (2014: 54\%) felt the move would be significantly in favour of electronic access. However, 39\% (2014: 39\%) considered that in the next five years in their library the balance would move only marginally in favour of electronic access. Just $8 \%(2014: 7 \%)$ felt the balance would remain constant. As in all previous surveys no respondents considered there would be a move away from electronic access. 
Consistently therefore respondents' views on the future have moved away from considering only a marginal move towards electronic provision possible, towards a majority considering a significant move towards electronic provision likely.

Looking at the differences between types of institution, 38\% (2014: $43 \%)$ of old universities felt the move towards electronic would be marginal, and a similar $38 \%(2014: 33 \%)$ of new universities also thought the move would be marginal. There was agreement in the proportion of old and new universities who thought the move towards electronic would be significant: $57 \%$ of old university respondents (2014: $50 \%$ ) and $52 \%$ of new university respondents (2014: 60\%) respectively.

Since 2004, when these questions were first posed, the views of the sectors have become more closely aligned, and now a high percentage of respondents in all sectors consider library provision will move significantly in favour of electronic delivery.

\subsection{Monographs v Serials}

Ninety fine (98\%) of respondents provided their views on the balance of expenditure between monographs and serials. The results consolidate trends established in past years. At $60 \%$, most respondents considered the balance would remain constant (2014: 56\%). 22\% of respondents considered that the balance would move marginally in favour of serials (2014: $22 \%$ ) and $17 \%$ of respondents considered that the balance would move marginally in favour of monographs (2014: 15\%). Only $1 \%$ of respondents thought the balance would move significantly in favour of serials (2014: 7\%) and no respondents thought the balance would move significantly in favour of monographs (2014: $0 \%)$.

There was majority agreement between respondents from old and new universities that the balance would remain constant.

\subsection{GB materials and EU materials v Foreign and International materials}

Finally, $95(98 \%)$ respondents provided their views on the changes over the next five years in the proportion spent in their library purchasing legal materials relating to the law of Great Britain and the European Union as compared with foreign and international law. The pattern is similar to that reported in the past four surveys.

At 59\%, most respondents considered the proportion would remain constant (2014: 67\%). $19 \%$ of respondents considered that the proportion would move marginally in favour of foreign and international (2014: $20 \%$ ) and 20\% thought the proportion would move marginally in favour of Great Britain and the EU (2014: 7\%). Only 1\% of respondents thought the proportion would move significantly in favour of Great Britain and the EU (2014: 5\%) and only $1 \%$ of respondents thought the proportion would move significantly in favour of foreign and international (2014: 1\%).

When analysed by type of institution there was a unanimity of response between old and new universities. Similar majority numbers (old $60 \%$ and new 58\%) believed that the proportion would remain constant.

Overall, there was considerable uniformity in responses between old and new universities on future trends across the higher education sector.

\section{Acknowledgement}

My job has been made considerably easier as usual by having Laura Griffiths, an Assistant Librarian at IALS, to fill the important administrative and statistical roles with her usual accuracy and efficiency. She continues to contribute significantly to the administration of the survey and has helped me by calculating many of the statistics for the report. 


\section{References}

Gee, David (2016) SLS/BIALL Academic Law Survey 2014/2015. Legal Information Management. 16(4), 239-257.

Gee, David (2015) SLS/BIALL Academic Law Survey 2013/2014. Legal Information Management. 15(4), 264-282.

Gee, David (2014) SLS/BIALL Academic Law Survey 2012/2013. Legal Information Management. 14(3), 215-233.

Gee, David (2013) SLS/BIALL Academic Law Survey 2011/2012. Legal Information Management. 13(4), 260-277.

Gee, David (2012) SLS/BIALL Academic Law Survey 2010/2011. Legal Information Management. 12(3), 218-232.

Society of Legal Scholars (2009) A library for the modern law school. A statement of standards for university law library provision in the United Kingdom - 2009 revision. Available at URL: http://www.legalscholars.ac.uk/documents/SLS-Library-for-a-Modern-Law-SchoolStatement-2009.pdf

\section{Appendix}

List of the 97 academic law libraries in the UK and Ireland that returned a completed 2016/2016 survey questionnaire

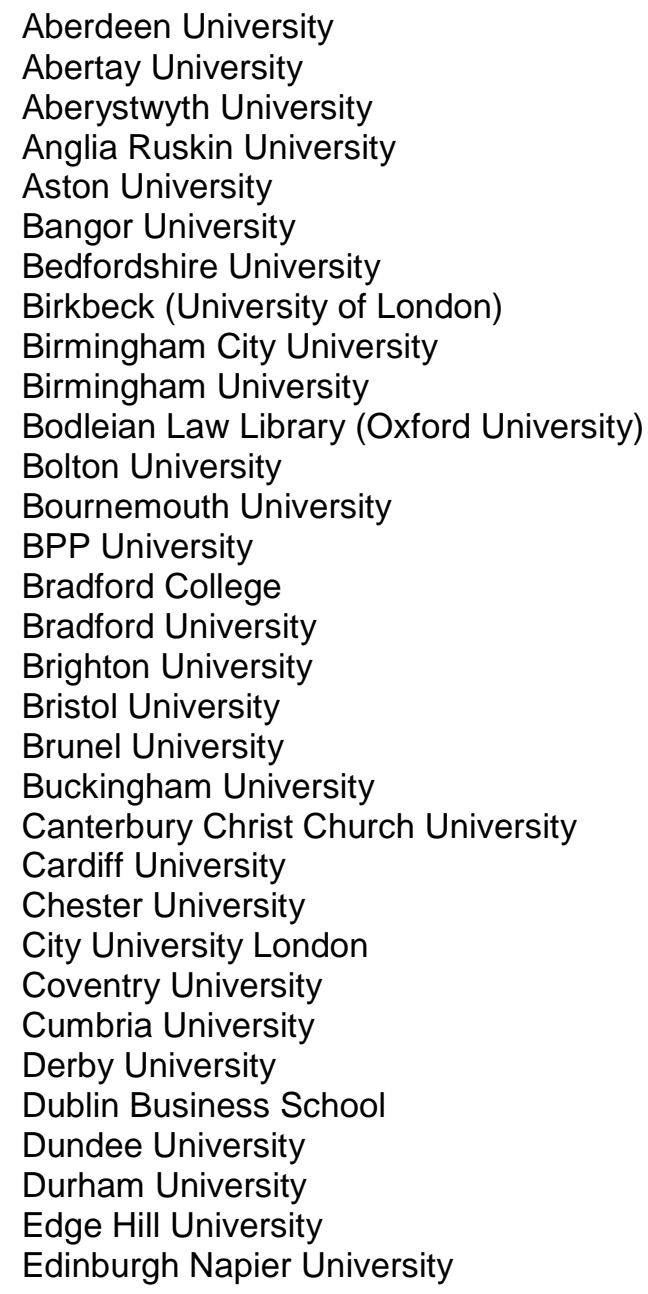




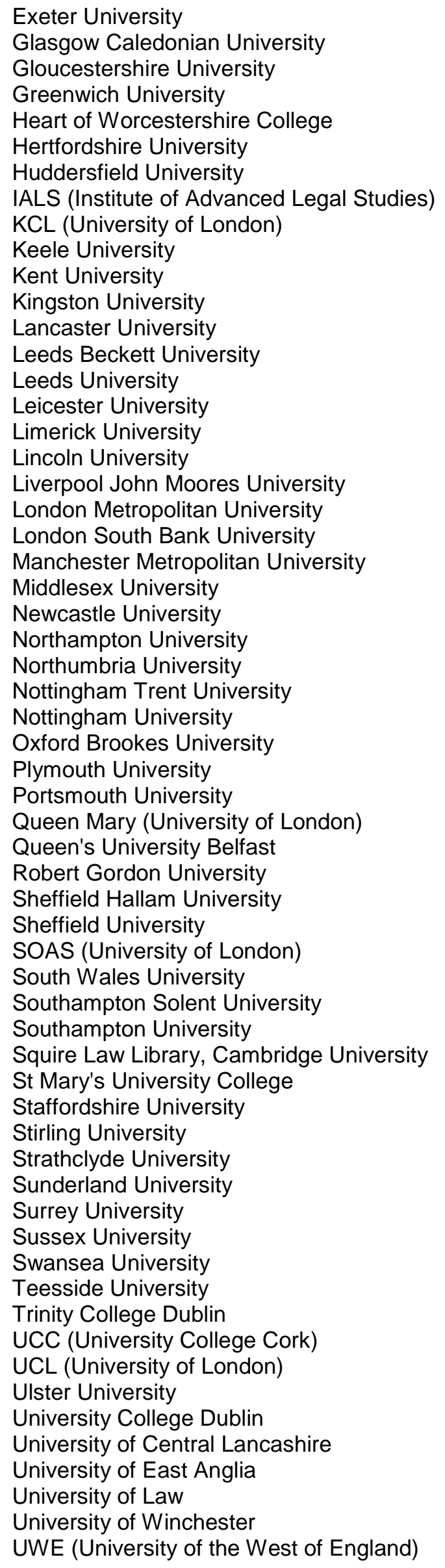


Warwick University

West London University

Westminster University

Wolverhampton University

York University

DG

20/7/17 